\title{
Breeding of Hibiscus sabdariffa L.: evaluation of resistance to Fusarium oxysporum Schlecht. Emend. Snyd. and Hans in two varieties
}

\section{Raoul Sylvère Sié ${ }^{1,2,3}$, Gilbert Charles ${ }^{2,3}$, Hortense Atta Diallo ${ }^{1}$, Daouda Koné ${ }^{4}$, Yannick Toueix $^{2,3}$, Yao Djè ${ }^{1}$ and Michel Branchard ${ }^{2,3}$}

${ }^{1}$ Laboratoire de Biologie et d'Amélioration des Productions Végétales, Université d'AboboAdjamé (UAA), 02 BP 801 Abidjan 02, Côte d'Ivoire; 'Laboratoire de Biotechnologie et de Physiologie Végétales, Université de Bretagne Occidentale (UBO), Technopôle Brest-Iroise, 29280 Plouzané, France; ${ }^{3}$ Université Européenne de Bretagne (UEB), France; ${ }^{4}$ Laboratoire de Physiologie Végétale, Université de Cocody (UC), 22 BP 582 Abidjan 22, Côte d'Ivoire

\begin{abstract}
Various diseases such as Fusarium wilt adversely affect the growth of roselle (Hibiscus sabdariffa L.) plant in various parts of the world. Two varieties (sabdariffa, altissima) of this species were inoculated in vitro and under nursery conditons. Non inoculated plants of each variety were used as control plants. The damages caused by the fungal attacks on the growth of plants was measured by their negative impact on the morphological traits such as length, width and fresh weight of leaves. According to the level of this negative impact on in vitro grown plantlets, sabdariffa plantlets were considered as more resistant to Fusarium oxysporum than altissima ones. In nursery, compared to their respective control, the values of the morphological traits of the inoculated plants increased in sabdariffa variety and decreased in altissima one. The inoculated in vitro plantlets of the sabdariffa variety had higher phenol content than those of altissima variety. In nursery, the variations of the total phenol content were negative for the sabdariffa variety and positive for altissima. Negative and highly significant correlations were observed between the resistance traits and the total phenolic content. $F$. oxysporum had no significant effect on photosynthesis of the plants of sabdariffa or altissima varieties.
\end{abstract}

Keywords: Hibiscus sabdariffa L., Fusarium oxysporum, early screening, resistance, total phenol,

\section{INTRODUCTION}

Roselle (Hibiscus sabdariffa L.) composed of two non fixed varieties sabdariffa and altissima, is a dicotyledonous and autogamous plant of the Malvaceae family and that is native to Africa (Boulanger et al., 1984; Gomez-Leyva et al., 2008). It is a tetraploid species with $2 n=4 x=72$ (Akpan, 2000) and widely grown in tropical and subtropical regions of both hemispheres and many areas of India and parts of Asia, America and Australia (Morton, 1987).

The calyx is used for producing drinks or tea due to its high contents of anthocyanins (Mizukami et al., 1988; Mizukami et al., 1989; Hong and Wrostlad, 1990), amino acids, and mineral salts (Cissé et al., 2009). Roselle is also cultivated for its fibers and organic compounds (Cissé et al., 2009).

In several countries, it is used as a natural medicine for treating hypertension (Faraji and Tarkhani, 1999), pyrexia and liver disorders (Chen et al., 2003), microorganism growth limitation (Oboh and Elusiyam, 2004), as well as a diuretic, digestive and sedative
(Akindahunsi and Olaleye, 2003). The fibers obtained from $H$. sabdariffa are generally less expensive to produce compared to fibers from most fiber crops (Fathima and Balasusbramanian, 2006). Pharmacological studies of anthocyanins of Hibiscus showed that they have antioxydant activity in patients with atherosclerosis (Tsai et al., 2002).

Diseases have been reported as a limiting factor to the production of roselle worldwide. The cultivated plants are susceptible to the various pathogens such as Phytophthora parasitica, Phoma sabdariffae, Rhizoctonia solani (Boulanger et al., 1984; GomezLeyva et al., 2008) and F. oxysporum (Amusa et al., 2005; Agbenin and Ogunlana, 2006). Ooi and Saleh (1999) reported $F$. oxysporum as the principal causal agent of vascular wilt. For Boulanger et al. (1984), F. oxysporum is the causal agent of stem pod of the young plants of $H$. sabdariffa.

In spite of its economic importance, there are a few or no report of roselle disease and selection in Côte d'Ivoire. One of the major axes of Hibiscus improvement programs consists of the development 
of resistant genotypes against fungal diseases. In order for future breeding programs to be carried out through hybridization of different genotypes of $H$. sabdariffa, a study focusing on some of the resistance mechanisms against $F$. oxysporum is necessary. The objective of the present study was to evaluate the resistance of cultivated plants of two varieties of $H$. sabdariffa at different ages in order to determine which can be used for early screening of Fusarium wilt and to relate the data to the roselle mechanisms of defense.

\section{MATERIALS AND METHODS}

Plant material: The seedlings of two varieties of Hibiscus sabdariffa L. (var. sabdariffa and var. altissima) obtained from seeds originated from Korhogo (North of Côte d'Ivoire), were used. All the seeds were disinfected with $5 \%(\mathrm{w} / \mathrm{v})$ calcium hypochloride for $10 \mathrm{~min}$ followed by 3 washes for 5 min each in sterile distilled water. The first group of seeds was germinated in Pyrex test tubes containing each $11 \mathrm{ml}$ of Murashige and Skoog medium (1962) supplemented with $2 \%$ sucrose (Sigma Chemical Co), Morel vitamins and solidified with 5,5\% agar (Sigma Chemical Co). Seeds were incubated for $24 \mathrm{~h}$ in darkness and then transferred in a growth chamber at $25 \pm 2{ }^{\circ} \mathrm{C}$ under $14 / 10 \mathrm{~h}$ photoperiod and $35 \mu{\mathrm{M} . \mathrm{m}^{-}}^{-}$ ${ }^{2} . \mathrm{s}^{-1}$ provided by cool white fluorescent lamps (Mazdafluor $58 \mathrm{~W}$ ) for 21 days. The second group of desinfected seeds was grown in pots containing sterilised composted sand. Five days later, the pots were transferred in a nursery under solar light, at 30 $\pm 2{ }^{\circ} \mathrm{C}, 12 / 12 \mathrm{~h}$ photoperiod and $75-85 \%$ of relative humidity. Watering was realized each two days.

Fungal material: Isolates of Fusarium oxysporum Schlecht Emend Snyd and Hans were obtained and screened in the Laboratoire de Biotechnologie et Physiologie Végétales (LBPV) of Université de Bretagne Occidentale (UBO) in France, from naturally infected seeds of roselle $(H$. sabdariffa). These seeds originated from farms of Korhogo (North of Côte d'Ivoire) and Burkina Faso, were sterilised with $5 \%(\mathrm{w} / \mathrm{v})$ calcium hypochloride for $10 \mathrm{~min}$ and rinsed three times for 5 min each in sterile distilled water. Fungal cultures were grown on Potato Dextrose Agar (PDA, DIFCO) medium in Petri dishes incubated at $25 \pm 1{ }^{\circ} \mathrm{C}$ in total darkness. Two weeks later, plates were inoculated by using an agar plug (90 $\mathrm{mm}$ in diameter) taken from the edge of the colony and placed at the centre of a PDA. Plate were incubated for 15 days at $25 \pm 1{ }^{\circ} \mathrm{C}$ in total darkness. The tubes were closed with sterile cotton. Conidia suspension was obtained in a mixture of sterile water and detergent.
Inoculation techniques: Five seedlings with 2 leaves, growing individually in tubes containing MS medium, were artificially inoculated by using $20 \mu \mathrm{l}$ of microconidial suspensions $\left(10^{7}\right.$ spores $\left./ \mathrm{ml}\right)$ of $F$. oxysporum isolates; five non-infected plants were used as control. The inoculation consisted of putting conidial suspensions on culture medium closest to each seedling. The infected seedlings were incubated in the same conditions as for their culture. For each treatment, the experiment was carried out in triplicates.

For plants in pots, seeds were first sown in pots containing sterile compost and grown in laboratory. Fourteen days later, the seedlings were transferred into pots containing the mixture of composted sand that was sterilized 2 times by autoclaving at $121{ }^{\circ} \mathrm{C}$ for $30 \mathrm{~min}$. Inoculation was performed by using high concentration of $F$. oxysporum. Then inoculated plants were transferred in nursery under open air, 12 $\mathrm{h}$ light regime and $30 \pm 2{ }^{\circ} \mathrm{C}$. Ten plants were used for each treatment and 5 plants for control. Each treatment was carried out with three replicates.

Measurements of traits: In culture in vitro, morphological performance of $H$. sabdariffa infected plants including fresh weight of leaves $\left(F W_{v}\right)$, number of leaves $\left(\mathrm{NL}_{v}\right)$ and height of plants $\left(\mathrm{HP}_{\mathrm{v}}\right)$ were measured at 5 and 10 days after inoculation (DAI). Biochemical parameters were measured through the contents of total phenols $\left(\mathrm{PHE}_{\mathrm{v}}\right)$, chlorophyll a $\left(C a_{v}\right)$, chlorophyll b $\left(\right.$ Chlb $\left._{v}\right)$, total chlorophyll (Chlt $\left.{ }_{v}\right)$ and carotene $\left(\mathrm{CAR}_{\mathrm{v}}\right)$. The damage caused by the fungic attacks on the roselle plants is expressed by their negative impact on the morphological traits. The responses of this species against $F$. oxysporum attacks were highlighted by biochemical parameters.

The content of total phenols in leaves was estimated using Folin-Ciocalteu $1 \mathrm{~N}$ reagent and spectrophotometrically measured at $765 \mathrm{~nm}$ wavelength ; it was expressed as $\mathrm{mg}^{-1} \mathrm{~g}^{-1}$ fresh weight of leaves (FW) (Spies, 1955 cited by Damodaran et al., 2009). Chlorophylls and carotenes were evaluated according to the following formula (Lichtenthaler, 1987):

$$
\begin{aligned}
& \text { Chlorophyll a (mg.g } \left.{ }^{-1} \mathrm{FW}\right): 12.25 \mathrm{~A}_{663}-2.79 \mathrm{~A}_{645} \\
& \text { Chlorophyll b (mg.g } \left.{ }^{-1} \mathrm{FW}\right): 21.50 \mathrm{~A}_{645}-5.10 \mathrm{~A}_{663} \\
& \text { Total Chlorophyll (mg.g } \left.{ }^{-1} \mathrm{FW}\right): 7.15 \mathrm{~A}_{663}+18.71 \mathrm{~A}_{645} \\
& 1000 \text { A470 - 1.82 Chla - 85.02 Chlb } \\
& \text { carotene : -------------- } 198
\end{aligned}
$$

A : absorbance 
When the control plants were significantly different between sabdariffa and altissima varieties, the impact of different treatments on morphological and biochemical traits was represented by the variation between each inoculated plants and the mean value of the control plants:

$$
\begin{aligned}
& \Delta=\frac{\mathrm{X}_{\mathrm{i}}-\overline{\mathrm{X}_{\mathrm{t}}}}{\overline{X_{\mathrm{t}}}} \times 100, \text { where } \\
& \mathrm{X}_{\mathrm{i}}=\text { individual values of inoculated plants } \\
& \mathrm{X}_{\mathrm{t}}=\text { mean value of traits in control plants }
\end{aligned}
$$

For the infected plants grown in nursery, the studied morphological traits were height of plants $\left(H P_{n}\right)$, length $\left(L L_{n}\right)$, width $\left(W L_{n}\right)$ and fresh weight $\left(F W_{n}\right)$ of leaves at 17 and $37 \mathrm{DAl}$ while biochemical traits were contents of total phenols $\left(\mathrm{PHE}_{\mathrm{n}}\right)$, chlorophyll a $\left(\mathrm{Chla}_{n}\right)$, chlorophyll b $\left(\mathrm{Chlb}_{n}\right)$, total chlorophyll $\left(\right.$ Chlt $\left._{n}\right)$ and carotene $\left(\mathrm{CAR}_{\mathrm{n}}\right)$ at $37 \mathrm{DAl}$.

Statistical analysis: The experiment was carried out in a completely randomized design with genotype as the only source of variation. All data were analysed using SPSS 10.1 statistical software. Comparison of means between the two varieties for the different morphological and biochemical traits were realised using t-test, while the relationships between the morphological and biochemical traits and then resistance were measured using the Pearson's correlation models.

\section{RESULTS}

Level of resistance: The level of resistance was evaluated through the negative impact of plant inoculation with $F$. oxysporum on the morphological traits.

Growth performance of the control plants of the roselle was evaluated in both culture in vitro and nursery. Comparison between control in vitro plantlets of sabdariffa and altissima varieties showed no significant difference for all morphological and biochemical traits except for height of plants at 10 days (Sié, 2010). For the morphological traits in the control plants grown in nursery, dimensions of the leaves of altissima variety were significantly higher than those of the sabdariffa variety $(P<0.05)$. No significant difference was observed for the plant height at 17 and $37 \mathrm{DAl}$. For the biochemical traits, control plants of the sabdariffa variety produced more contents of total phenols and chlorophyll $b$, than the altissima variety (Sié, 2010).

The growth performance of in vitro plantlets of roselle when they were treated with the inoculum containing $10^{7}$ spores $/ \mathrm{ml}$ of $F$. oxysporum, was listed in table 1 . After $5 \mathrm{DAl}$, the height of plants, fresh weight and number of leaves of the sabdariffa variety were significantly higher than those observed in altissima variety. These values obtained in sabdariffa variety were respectively $125 \%, 150 \%$ and $131 \%$ of those observed in the altissima variety. At $10 \mathrm{DAl}$, only the height of plants differentiated the sabdariffa variety $(4.19 \mathrm{~cm})$ from the altissima one $(3.32 \mathrm{~cm})$.

Generally, the treated plants of both sabdariffa and altissima varieties had a lower growth than the control ones (Tables 2,3). When treated with $F$. oxysporum, the in vitro plantlets were not generally significantly different for the growth performance (Sié, 2010) but for the biochemical traits, only the content of total phenols $10 \mathrm{DAl}$ and the content of carotene 5 DAl showed significant differences between the sabdariffa and altissima varieties (Tab. 4). Indeed, from the $5^{\text {th }}$ to $10^{\text {th }}$ DAI, the content of total phenols in sabdariffa variety increased while it decreased in altissima variety (Fig. 1). Note that the measured total phenols at the day of the inoculation were respectively $4.95 \mathrm{mg}^{-1} \mathrm{FW}$ and $6.40 \mathrm{mg}^{-1} \mathrm{~g}^{-1} \mathrm{FW}$ for sabdariffa and altissima varieties.

\begin{tabular}{|c|c|c|c|c|c|c|}
\hline Varieties & $\begin{array}{c}F W_{v} 5 D \\
(g)\end{array}$ & $\begin{array}{c}F W_{v} 10 D \\
(g)\end{array}$ & $H P_{v} 5 D(\mathrm{~cm})$ & $H P_{v} 10 D(\mathrm{~cm})$ & $N L_{v} 5 D$ & $N L_{v} 10 D$ \\
\hline sabdariffa & $0.12 \pm 0.02^{b}$ & $0.08 \pm 0.01^{a}$ & $4.71 \pm 0.67^{b}$ & $4.19 \pm 0.69^{b}$ & $2.93 \pm 0.26^{b}$ & $2.93 \pm 0.59^{\mathrm{a}}$ \\
\hline altissima & $0.08 \pm 0.00^{\mathrm{a}}$ & $0.07 \pm 0.02^{a}$ & $3.77 \pm 0.56^{a}$ & $3.32 \pm 0.36^{a}$ & $2.23 \pm 0.44^{\mathrm{a}}$ & $2.85 \pm 0.37^{\mathrm{a}}$ \\
\hline $\mathrm{P}^{\text {Significance }}$ & 0.046 & $0.219^{\text {ns }}$ & $0.000^{\text {tax }}$ & 0.000 & 0.000 & $0.652^{\text {ns }}$ \\
\hline
\end{tabular}

Table 1 : Comparison between the vitroplants of Hibiscus sabdariffa var. sabdariffa and $H$. sabdariffa var. altissima inoculated with $10^{7}$ spores $/ \mathrm{ml}$ of $F$. oxysporum for the morphological traits

Means within the same column followed by the same letters are not significantly different

ns : not significant at $5 \% \quad{ }^{*}$ : significant at $5 \% \quad{ }^{* * *}$ : significant at $0.1 \%$

FW 5 DAl: fresh weight of leaves at 5 days after inoculation

HP 5 DAl: height of plants at 5 days after inoculation

$\mathrm{NL}_{v} 5 \mathrm{DAl}$ : number of leaves at 5 days after inoculation 
Agric. Biol. J. N. Am., 2011, 2(1): 125-133

Table 2 : Comparison between the control plants and the inoculated vitroplants of Hibiscus sabdariffa var. sabdariffa with $10^{7}$ spores $/ \mathrm{ml}$ of $F$. oxysporum for the morphological traits

\begin{tabular}{|c|c|c|c|c|c|c|}
\hline Treatments & $\begin{array}{c}F W_{v} 5 D \\
(g)\end{array}$ & $\begin{array}{c}F W_{v} 10 D \\
(g)\end{array}$ & $H P_{v} 5 D(\mathrm{~cm})$ & $H P_{v} 10 D(\mathrm{~cm})$ & $N L_{v} 5 D$ & $N L_{v} 10 D$ \\
\hline Control & $0,20 \pm 0,05^{\mathrm{b}}$ & $0,12 \pm 0,10^{\mathrm{a}}$ & $6,18 \pm 0,70^{\mathrm{b}}$ & $7,86 \pm 1,09^{\mathrm{b}}$ & $2,93 \pm 0,27^{\mathrm{b}}$ & $3,86 \pm 0,38^{\mathrm{b}}$ \\
\hline $10^{\prime}$ & $0,12 \pm 0,02^{\mathrm{a}}$ & $0,08 \pm 0,01^{\mathrm{a}}$ & $4,71 \pm 0,73^{\mathrm{a}}$ & $4,19 \pm 0,69^{\mathrm{a}}$ & $2,83 \pm 0,64^{\mathrm{a}}$ & $2,93 \pm 0,59^{\mathrm{a}}$ \\
\hline $\mathrm{P}^{\text {Signification }}$ & $0,013^{*}$ & $0,537^{\mathrm{ns}}$ & $0,000^{* *}$ & $0,000^{*}$ & $0,018^{*}$ & $0,000^{*}$ \\
\hline
\end{tabular}

Means within the same column followed by the same letters are not significantly different

ns : not significant at $5 \% \quad{ }^{*}$ : significant at $5 \% \quad{ }^{* *}$ : significant at $1 \%{ }^{* * *}$ : significant at $0.1 \%$

FW 5 DAl: fresh weight of leaves at 5 days after inoculation

$\mathrm{HP}_{\mathrm{v}}$ 5DAl: height of plants at 5 days after inoculation

$\mathrm{NL}_{v}$ 5DAl: number of leaves at 5 days after inoculation

Table 3 : Comparison between the control plants and the inoculated vitroplants of Hibiscus sabdariffa var. altissima with $10^{7}$ spores $/ \mathrm{ml}$ of $F$. oxysporum for the morphological traits

\begin{tabular}{|c|c|c|c|c|c|c|}
\hline Treatments & $\begin{array}{c}F W_{v} 5 D \\
(g)\end{array}$ & $\begin{array}{c}F W_{v} 10 D \\
(g)\end{array}$ & $H P_{v} 5 D(\mathrm{~cm})$ & $H P_{v} 10 D(\mathrm{~cm})$ & $N L_{v} 5 D$ & $N L_{v} 10 D$ \\
\hline Control & $0,16 \pm 0,04^{\mathrm{b}}$ & $0,14 \pm 0,01^{\mathrm{b}}$ & $4,90 \pm 1,14^{\mathrm{b}}$ & $5,73 \pm 1,95^{\mathrm{b}}$ & $3,00 \pm 0,00^{\mathrm{a}}$ & $4,00 \pm 0,00^{\mathrm{b}}$ \\
\hline $10^{\prime}$ & $0,08 \pm 0,00^{\mathrm{a}}$ & $0,07 \pm 0,02^{\mathrm{a}}$ & $3,77 \pm 0,56^{\mathrm{a}}$ & $3,32 \pm 0,36^{\mathrm{a}}$ & $2,85 \pm 0,37^{\mathrm{a}}$ & $2,85 \pm 0,38^{\mathrm{a}}$ \\
\hline $\mathrm{P}^{\text {signification }}$ & $0,014^{*}$ & $0,003^{*}$ & $0,038^{* *}$ & $0,000^{* *}$ & $0,610^{\mathrm{ns}}$ & $0,000^{* *}$ \\
\hline
\end{tabular}

Means within the same column followed by the same letters are not significantly different

ns : not significant at $5 \% \quad{ }^{*}$ : significant at $5 \% \quad{ }^{* *}$ : significant at $1 \%{ }^{* *}$ : significant at $0.1 \%$

$\mathrm{FW}_{\mathrm{v}} 5 \mathrm{DAl}$ : fresh weight of leaves at 5 days after inoculation

$\mathrm{HP}_{\mathrm{v}}$ 5DAl: height of plants at 5 days after inoculation

$\mathrm{NL}_{v} 5 \mathrm{DAl}$ : number of leaves at 5 days after inoculation

Table 4 : Comparison between the vitroplants of Hibiscus sabdariffa var. sabdariffa and $H$. sabdariffa var. altissima inoculated with $10^{7}$ spores $/ \mathrm{ml}$ of $F$. oxysporum for the biochemical traits

\begin{tabular}{|c|c|c|c|c|c|c|c|c|c|c|}
\hline Genotypes & $\mathrm{Phe}_{\mathrm{v}} 5 \mathrm{DAl}$ & $\mathrm{Phe}_{\mathrm{v}}$ 10DAl & $\mathrm{Chla}_{\mathrm{v}} 5 \mathrm{DAl}$ & Chla ${ }_{v} 10 \mathrm{DAl}$ & $\mathrm{Chlb}_{\mathrm{v}} 5 \mathrm{DAl}$ & $\mathrm{Chlb}_{\mathrm{v}} 10 \mathrm{DAl}$ & Chlt $_{\mathrm{v}} 5 \mathrm{DAl}$ & Chlt $_{v}$ 10DAl & $\mathrm{Car}_{\mathrm{v}} 5 \mathrm{DAl}$ & $\mathrm{Car}_{\mathrm{v}}$ 10DAl \\
\hline sabdariffa & $\begin{array}{c}2.72 \pm 0.24 \\
a\end{array}$ & $\begin{array}{c}3.67 \pm 0.30 \\
b\end{array}$ & $22.83 \pm 36.82$ & $0.71 \pm 0.18$ & $14.35 \pm 21.03$ & $1.56 \pm 0.48$ & $50.52 \pm 80.94$ & $2.28 \pm 0.63$ & $0.11 \pm 1.43$ & $0.53 \pm 0.13$ \\
\hline altissima & $\begin{array}{c}2.97 \pm 1.36 \\
a\end{array}$ & $\begin{array}{c}2.74 \pm 0.28 \\
a\end{array}$ & $46.49 \pm 15.86$ & $1.06 \pm 0.53$ & $18.54 \pm 9.61$ & $1.67 \pm 0.64$ & $65.04 \pm 25.26$ & $2.73 \pm 0.71$ & $15.06 \pm 1.28$ & $0.75 \pm 0.57$ \\
\hline $\mathrm{P}^{\text {significance }}$ & $0.769^{\mathrm{ns}}$ & $0.017^{*}$ & $0.364^{\mathrm{ns}}$ & $0.333^{\mathrm{ns}}$ & $0.769^{\mathrm{ns}}$ & $0.865^{\mathrm{ns}}$ & $0.782^{\mathrm{ns}}$ & $0.449^{\mathrm{ns}}$ & $0.000^{*}$ & $0.551^{\mathrm{ns}}$ \\
\hline
\end{tabular}

Means within the same column followed by the same letters are not significantly different

ns : not significant at $5 \% \quad *$ : significant at $5 \% \quad * * *$ : significant at $0.1 \%$

$\mathrm{PHE}_{\mathrm{v}}$ 5DAl: content of total phenols at 5 days after inoculation $\quad$ Chla $5 \mathrm{DAl}$ : content of chlorophyll a at 5 days after inoculation

Chlb 5 DAl: content of chlorophyll b at 5 days after inoculation

Chlt ${ }_{v} 5 \mathrm{DAl}$ : content of total chlorophyll at 5 days after $\mathrm{CAR}_{n} 5 \mathrm{DAl}$ : content of carotene at 5 days after inoculation inoculation

Table 5 : Effect of Fusarium oxysporum on plants of two varietes (sabdariffa, altissima) of Hibiscus sabdariffa compared to the control ones for morphological traits in nursery

\begin{tabular}{|c|c|c|c|c|c|}
\hline Varieties & \multicolumn{5}{|c|}{ Variation of morphological traits (\%) } \\
\hline & $\begin{array}{l}\mathrm{HP}_{\mathrm{n}} \text { 17DAI } \\
(\mathrm{cm})\end{array}$ & $\begin{array}{l}\mathrm{HP}_{\mathrm{n}} 37 \mathrm{DAl} \\
(\mathrm{cm})\end{array}$ & $\begin{array}{l}\text { LL }_{n} 37 \mathrm{DAI} \\
(\mathrm{cm})\end{array}$ & $\begin{array}{c}\mathrm{WL}_{n} 37 \mathrm{DAl} \\
(\mathrm{cm})\end{array}$ & $\begin{array}{c}\text { FW }_{\mathrm{n}} 37 \mathrm{DAl} \\
(\mathrm{g})\end{array}$ \\
\hline sabdariffa & $+29.22 \pm 26.87^{a}$ & $+22.87 \pm 24.13^{\mathrm{a}}$ & $+13.99 \pm 16.74^{\mathrm{a}}$ & $+13.04 \pm 13.67^{a}$ & $+51.26 \pm 43.43^{a}$ \\
\hline altissima & $+27.63 \pm 49.70^{\mathrm{a}}$ & $+9.70 \pm 32.94^{\mathrm{a}}$ & $-33.22 \pm 16.64^{b}$ & $-35.52 \pm 13.14^{b}$ & $-59.21 \pm 16.23^{b}$ \\
\hline $\mathrm{P}^{\text {significance }}$ & $0.934^{\mathrm{ns}}$ & $0.348^{\text {ns }}$ & 0.000 & 0.000 & 0.000 \\
\hline
\end{tabular}

Means within the same column followed by the same letters are not significantly different

ns : not significant at $5 \%$

$\mathrm{HP}_{\mathrm{n}} 17 \mathrm{D}$ : height of plants at 17 days $\mathrm{HP}_{\mathrm{n}} 37 \mathrm{D}$ : height of plants at 37 days

$\mathrm{LL}_{n} 37 \mathrm{D}$ : lenght of leaves at 37 days $\quad \mathrm{WL}_{n} 37 \mathrm{D}$ : width of leaves at 37 days

$\mathrm{FW}_{\mathrm{n}} 37 \mathrm{D}$ : fresh weight of leaves at 37 days 
Agric. Biol. J. N. Am., 2011, 2(1): 125-133

Table 6 : Effect of Fusarium oxysporum on plants of two varieties (sabdariffa, altissima) of Hibiscus sabdariffa compared to the control ones for biochemical traits in nursery

\begin{tabular}{|c|c|c|c|c|c|}
\hline Varieties & \multicolumn{5}{|c|}{ Variation of biochemical traits (\%) } \\
\hline & $\begin{array}{c}\mathrm{PHE}_{\mathrm{n}}\left(\mathrm{mg} \cdot \mathrm{g}^{-1}\right. \\
\mathrm{FW})\end{array}$ & Chla $_{\mathrm{n}}\left(\mathrm{mg} \cdot \mathrm{g}^{-1} \mathrm{FW}\right)$ & $\begin{array}{c}\text { Chlb }_{\mathrm{n}} \\
\left(\mathrm{mg} \cdot \mathrm{g}^{-1} \mathrm{WF}\right)\end{array}$ & Chlt $_{\mathrm{n}}\left(\mathrm{mg}^{-1} \mathrm{~g}^{-1} \mathrm{FW}\right)$ & $\mathrm{CAR}_{\mathrm{n}}$ \\
\hline sabdariffa & $-49.07 \pm 12.21^{\mathrm{a}}$ & $-0.32 \pm 6.23^{\mathrm{a}}$ & $-4.84 \pm 12.16^{\mathrm{a}}$ & $-8.08 \pm 5.24^{\mathrm{a}}$ & $-11.83 \pm 16.57^{\mathrm{a}}$ \\
\hline altissima & $+185.99 \pm 150.34$ & $-6.35 \pm 13.50^{\mathrm{a}}$ & $+34.12 \pm 23.98^{\mathrm{b}}$ & $+0.40 \pm 14.10^{\mathrm{a}}$ & $+4.32 \pm 16.70^{\mathrm{a}}$ \\
\hline $\mathrm{P}^{\text {significance }}$ & 0.002 & $0.242^{\mathrm{ns}}$ & $0.000^{\mathrm{m}}$ & $0.110^{\mathrm{ns}}$ & $0.056^{\mathrm{ns}}$ \\
\hline
\end{tabular}

Means within the same column followed by the same letters are not significantly different

ns : not significant at $5 \% \quad{ }^{* *}$ : significant at $1 \% \quad{ }^{* * *}$ : significant at $0.1 \%$

$\mathrm{PHE}_{\mathrm{n}}$ : content of total phenols

Chlb $_{n}$ : content of chlorophyll b

Chla ${ }_{n}$ : content of chlorophyll a

$\mathrm{CAR}_{\mathrm{n}}$ : content of carotene

Chlt $_{n}$ : content of total chlorophyll

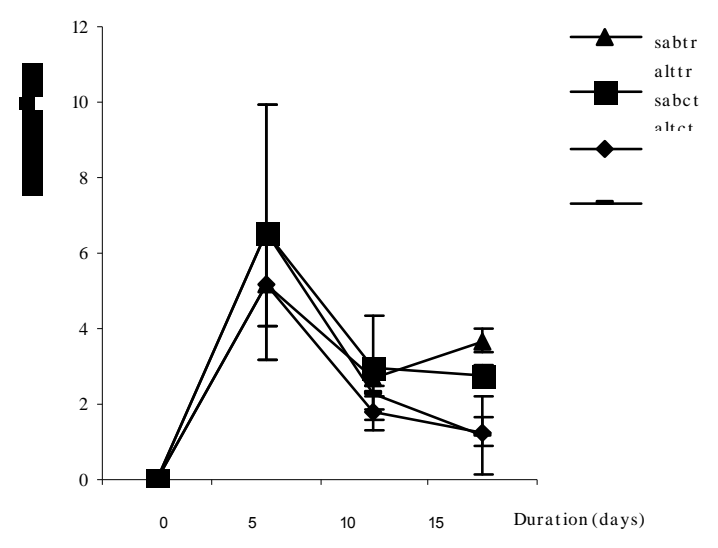

Figure 1: Evolution of total phenols in control (sabct, altct) and plants of sabdariffa and altissima varieties of Hibiscus sabdariffa treated (sabtr, alttr) with Fusarium oxysporum

In nursery, there was no significant difference between the treated plants of sabdariffa and altissima varieties for the biochemical traits (Sié, 2010). Table 5 presents the variation between the treated plants and those used as control in sabdariffa and altissima varieties for morphological traits. The length, the width and the fresh weight of leaves in treated plants of sabdariffa variety, increased $(+13.04 \%$ to 51.26 $\%)$ compared to their control plants while these traits decreased $(-33.22 \%$ to $-59.20 \%)$ in altissima variety. Treatment had a significant and negative effect on the genotypes of altissima variety but seemed to be favourable to sabdariffa genotypes. Altissima could be considered as a susceptible variety to $F$. oxysporum and sabdariffa, as a resistant one.

Compared to the control plants in both varieties (Tab. 6 ), the contents of the total phenols and the chlorophyll b decreased highly in sabdariffa variety (respectively $-49.07 \%$ and $-4.84 \%$ ) while these traits increased in altissima variety (respectively +185.99
$\%$ and $+34.12 \%)$. These differences for these traits were significant between the two varieties.

Correlations between morphological and biochemical traits for resistance: Fifteen out of 91 correlations were significant at the $5 \%$ probability level (Tab. 7). Because of natural strong and positive correlations between the traits concerning dimensions of leaves, only the coefficients of correlations between the morphological traits and the biochemical ones were considered in this work. However, height of in vitro plantlets 5 DAI was fairly and significantly correlated to height of plants $17 \mathrm{DAI}$ in nursery $(r=0.511)$.

The content of total phenols was significantly and negatively correlated with the length, width and fresh weight of leaves in the treated plants. A strong and negative correlation was observed between the content of total phenols and the leaf fresh weight $(r=$ -0.741 ). When the resistance of plants was high with a high weight of leaves, the content of total phenols was lower. 
Agric. Biol. J. N. Am., 2011, 2(1): 125-133

Table 7 : Correlations between the morphological and physiological traits measured on vitroplants $(v)$ and plants in nursery (n), inoculated by $10^{7}$ spores $/ \mathrm{ml}$ of Fusarium oxysporum

\begin{tabular}{|c|c|c|c|c|c|c|c|c|c|c|c|c|c|}
\hline & $\begin{array}{c}\mathrm{HP}_{\mathrm{n}} 17 \\
\mathrm{DAl}\end{array}$ & $\begin{array}{c}\mathrm{HP}_{\mathrm{n}} 37 \\
\mathrm{DAl}\end{array}$ & $\begin{array}{c}\mathrm{LL}_{\mathrm{n}} 37 \\
\mathrm{DAl}\end{array}$ & $\begin{array}{c}W_{n} 37 \\
\text { DAI }\end{array}$ & $\begin{array}{c}\mathrm{FW}_{\mathrm{n}} 37 \\
\mathrm{DAl}\end{array}$ & $\begin{array}{c}\text { Chla }_{\mathrm{n}} 37 \\
\text { DAl }\end{array}$ & $\begin{array}{c}\text { Chlb }_{\mathrm{n}} 37 \\
\text { DAl }\end{array}$ & $\begin{array}{c}\text { Chlt }_{\mathrm{n}} 37 \\
\text { DAI }\end{array}$ & $\begin{array}{c}\mathrm{CAR}_{\mathrm{n}} 37 \\
\mathrm{DAI}\end{array}$ & $\begin{array}{c}\mathrm{PHE}_{\mathrm{n}} 37 \\
\text { DAI }\end{array}$ & $\begin{array}{c}\mathrm{HP}_{\mathrm{v}} 5 \\
\mathrm{DAl}\end{array}$ & $\begin{array}{c}\mathrm{HP}_{\mathrm{v}} 1 \\
0 \\
\mathrm{DAl}\end{array}$ & $\begin{array}{c}\mathrm{NL}_{\mathrm{v}} 5 \\
\mathrm{DAl}\end{array}$ \\
\hline $\begin{array}{l}\mathrm{HP}_{\mathrm{n}} 37 \mathrm{DAl} \\
\text { Significance }\end{array}$ & $\underset{* *}{0.630}$ & & & & & & & & & & & & \\
\hline $\begin{array}{c}\text { LL 37DAI } \\
\text { Significance }\end{array}$ & $\begin{array}{c}0.227 \\
n s\end{array}$ & $\begin{array}{c}-0.131 \\
n s\end{array}$ & & & & & & & & & & & \\
\hline $\begin{array}{l}\mathrm{WL}_{n} 37 \mathrm{DAl} \\
\text { Significance }\end{array}$ & $\begin{array}{c}0.219 \\
\mathrm{~ns}\end{array}$ & $\begin{array}{c}0.044 \\
\mathrm{~ns}\end{array}$ & $\underset{* * *}{0.818}$ & & & & & & & & & & \\
\hline $\begin{array}{l}\mathrm{FW} \text { 37DAl } \\
\text { Significance }\end{array}$ & $\begin{array}{c}0.091 \\
\mathrm{~ns}\end{array}$ & $\begin{array}{c}-0.104 \\
n s\end{array}$ & $\underset{* * *}{0.796}$ & 0.864 & & & & & & & & & \\
\hline $\begin{array}{l}\text { Chla }_{n} 37 D A I \\
\text { Significance }\end{array}$ & $\begin{array}{c}0.276 \\
\mathrm{~ns}\end{array}$ & $\begin{array}{c}-0.335 \\
n s\end{array}$ & $\begin{array}{c}0.371 \\
\mathrm{~ns}\end{array}$ & $\begin{array}{c}0.071 \\
\mathrm{~ns}\end{array}$ & $\begin{array}{c}0.235 \\
\mathrm{~ns}\end{array}$ & & & & & & & & \\
\hline $\begin{array}{l}\text { Chlb } 37 D A l \\
\text { Significance }\end{array}$ & $\begin{array}{c}0.270 \\
n s\end{array}$ & $\begin{array}{c}-0.159 \\
n s\end{array}$ & $\begin{array}{c}0.036 \\
\text { ns }\end{array}$ & $\begin{array}{c}-0.011 \\
n s\end{array}$ & $\begin{array}{c}-0.057 \\
n s\end{array}$ & $\begin{array}{c}0.456 \\
\mathrm{~ns}\end{array}$ & & & & & & & \\
\hline $\begin{array}{l}\text { Chlt }_{\text {3 }} \text { SDAl } \\
\text { Significance }\end{array}$ & $\begin{array}{c}0.306 \\
n s\end{array}$ & $\begin{array}{c}-0.364 \\
n s\end{array}$ & $\begin{array}{c}0.328 \\
\text { ns }\end{array}$ & $\begin{array}{c}0.070 \\
n s\end{array}$ & $\begin{array}{c}0.227 \\
\mathrm{~ns}\end{array}$ & 0.958 & $\underset{* *}{0.607}$ & & & & & & \\
\hline $\begin{array}{l}\mathrm{CAR}_{\mathrm{n}} 37 \mathrm{DAl} \\
\text { Significance }\end{array}$ & $\begin{array}{c}0.005 \\
n s\end{array}$ & $\begin{array}{c}-0.383 \\
n s\end{array}$ & $\begin{array}{c}0.120 \\
\mathrm{~ns}\end{array}$ & $\begin{array}{c}-0.075 \\
n s\end{array}$ & $\begin{array}{c}0.134 \\
\mathrm{~ns}\end{array}$ & $\underset{*}{0.577}$ & $\begin{array}{c}0.044 \\
\text { ns }\end{array}$ & $\underset{* *}{0.620}$ & & & & & \\
\hline $\begin{array}{l}\mathrm{PHE}_{n} 37 \mathrm{DAl} \\
\text { Significance }\end{array}$ & $\begin{array}{c}-0.121 \\
n s\end{array}$ & $\begin{array}{c}0.012 \\
\mathrm{~ns}\end{array}$ & $\underset{*}{-0.555}$ & $\underset{* * *}{-0.713}$ & $\begin{array}{c}-0.741 \\
* * *\end{array}$ & $\begin{array}{c}0.006 \\
n s\end{array}$ & $\begin{array}{c}-0.027 \\
n s\end{array}$ & $\begin{array}{c}0.007 \\
\text { ns }\end{array}$ & $\begin{array}{c}0.067 \\
\text { ns }\end{array}$ & & & & \\
\hline $\begin{array}{c}\mathrm{HP}_{\mathrm{v}} 5 \mathrm{DAl} \\
\text { Significance }\end{array}$ & $\begin{array}{c}0.511 \\
*\end{array}$ & $\begin{array}{c}0.282 \\
\mathrm{~ns}\end{array}$ & $\begin{array}{c}-0.260 \\
n s\end{array}$ & $\begin{array}{c}-0.163 \\
n s\end{array}$ & $\begin{array}{c}-0.286 \\
n s\end{array}$ & $\begin{array}{c}0.090 \\
\mathrm{~ns}\end{array}$ & $\begin{array}{c}0.260 \\
\mathrm{~ns}\end{array}$ & $\begin{array}{c}0.138 \\
n s\end{array}$ & $\begin{array}{c}-0.227 \\
\mathrm{~ns}\end{array}$ & $\begin{array}{c}0.138 \\
\mathrm{~ns}\end{array}$ & & & \\
\hline $\begin{array}{l}\mathrm{HP}_{\mathrm{v}} 10 \mathrm{DAl} \\
\text { Significance }\end{array}$ & $\begin{array}{c}0.304 \\
\mathrm{~ns}\end{array}$ & $\begin{array}{c}0.188 \\
n s\end{array}$ & $\begin{array}{c}-0.100 \\
\text { ns }\end{array}$ & $\begin{array}{c}0.113 \\
\mathrm{~ns}\end{array}$ & $\begin{array}{c}-0.118 \\
\mathrm{~ns}\end{array}$ & $\begin{array}{c}-0.280 \\
\mathrm{~ns}\end{array}$ & $\begin{array}{c}0.105 \\
\mathrm{~ns}\end{array}$ & $\begin{array}{c}-0.193 \\
n s\end{array}$ & $\begin{array}{c}-0.488 \\
*\end{array}$ & $\begin{array}{c}-0.071 \\
\text { ns }\end{array}$ & $\underset{* * *}{0.785}$ & & \\
\hline $\begin{array}{c}\mathrm{NL}_{v} 5 \mathrm{DAl} \\
\text { Significance }\end{array}$ & $\begin{array}{c}0.278 \\
\mathrm{~ns}\end{array}$ & $\begin{array}{c}0.145 \\
\mathrm{~ns}\end{array}$ & $\begin{array}{c}0.472 \\
*\end{array}$ & $\begin{array}{c}0.233 \\
\mathrm{~ns}\end{array}$ & $\begin{array}{c}0.217 \\
\mathrm{~ns}\end{array}$ & $\begin{array}{c}-0.060 \\
n s\end{array}$ & $\begin{array}{c}0.084 \\
\mathrm{~ns}\end{array}$ & $\begin{array}{c}-0.038 \\
n s\end{array}$ & $\begin{array}{c}-0.266 \\
n s\end{array}$ & $\begin{array}{c}-0.116 \\
\text { ns }\end{array}$ & $\begin{array}{c}0.013 \\
\text { ns }\end{array}$ & $\begin{array}{c}0.092 \\
n s\end{array}$ & \\
\hline $\begin{array}{c}\mathrm{NL}_{v} 10 \mathrm{DAl} \\
\text { Significance }\end{array}$ & $\begin{array}{c}0.273 \\
n s\end{array}$ & $\begin{array}{c}0.251 \\
\mathrm{~ns}\end{array}$ & $\begin{array}{c}-0.086 \\
n s\end{array}$ & $\begin{array}{c}0.103 \\
n s\end{array}$ & $\begin{array}{c}0.157 \\
\text { ns }\end{array}$ & $\begin{array}{c}-0.214 \\
n s\end{array}$ & $\begin{array}{c}0.439 \\
\mathrm{~ns}\end{array}$ & $\begin{array}{c}-0 ., 081 \\
\text { ns }\end{array}$ & $\begin{array}{c}-0.182 \\
n s\end{array}$ & $\begin{array}{c}-0.385 \\
n s\end{array}$ & $\begin{array}{c}0.186 \\
\text { ns }\end{array}$ & $\begin{array}{c}0.179 \\
\text { ns }\end{array}$ & $\begin{array}{c}0.304 \\
n s\end{array}$ \\
\hline \multicolumn{14}{|c|}{ 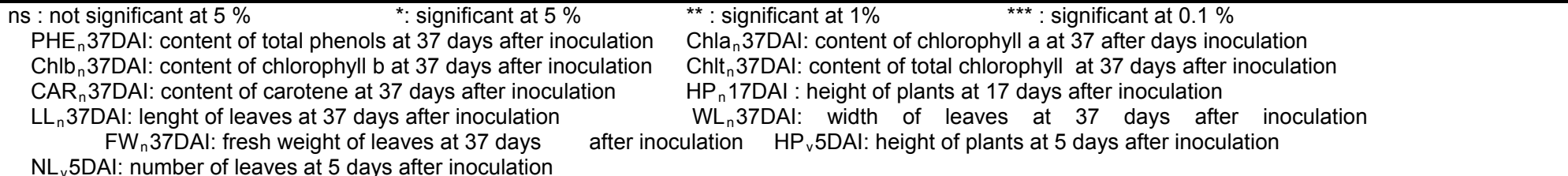 } \\
\hline
\end{tabular}




\section{DISCUSSION}

An important genotype effect was highlighted in vitro plantlets contaminated with $F$. oxysporum. Indeed, concentration of $10^{7}$ spores $/ \mathrm{ml}$ differentiated the two varieties for weight, height and number of leaves at 5 DAI. The individuals of sabdariffa variety were more resistant than the altissima ones. In date palm which were grown in nursery, resistant varieties against $F$. oxysporum were screened with $20 \mathrm{ml}$ of $10^{4}$ and $10^{6}$ spores $/ \mathrm{ml}$ (Sedra and Besri, 1994) and $4.10^{6}$ spores $/ \mathrm{ml}$ (El Modafar et al., 1999). For Phytophthora palmivora, pathogenic fungus of other Malvaceae such as cocoa tree, concentration of the used inoculum were $3.10^{5}$ spores $/ \mathrm{ml}$ (Tahi et al., 2000; Tahi et al., 2006).

In nursery, when the variation between the treated plants and the control ones was considered, the parameters length, width and weight of leaves increased for sabdariffa variety while these traits decreased for altissima variety. These results confirmed the relative resistance of sabdariffa variety and the susceptibility of altissima variety. Such susceptibility of certain plants against $F$. oxysporum were also observed in Strawberry (Zhao et al., 2009). The method of evaluation of the disease impact on plant involving measuring of the growth parameters and biomass were also used in strawberry (Zhao et al., 2009). In nursery this method seemed to express more the damages caused by the pathogenic agent than visual score of symptoms used in other plants for $P$. palmivora (Tahi et al., 2000).

The contents of total phenols in both treated varieties (sabdariffa and altissima) were higher than their control plants. The content in total phenols, which are involved in defense mechanisms against pathogens in several plants such as date palm (Ziouti et al., 1992), apple tree (Michaelek et al., 1996) or cassava (Dogbo et al., 2007; Dogbo et al., 2008), was higher in treated plants with $F$. oxysporum than the control ones in both varieties. These compounds could be produced in response to the attacks of pathogens.

When the time course accumulation of total phenols was considered from the day of the inoculation, this trait decreased continuously in altissima variety. In sabdariffa variety the content of total phenols decreased gradually from the day of the inoculation to the $5^{\text {th }} \mathrm{DAl}$ and then increased. Moreover, the initial content of total phenols in altissima variety was higher than that which was observed in sabdariffa variety. The total phenols in our study was probably composed of certain compounds which would be flavanes, flavonoids and hydroxycinnamic acids occurred in date palm exposed to $F$. oxysporum (Ziouti et al., 1992; El-Hadrami et al., 1996; Ramos et al., 1997). Thus, the decrease of the total phenols could be one of the constitutive compounds in sabdariffa variety while other non-constitutive phenolic compounds were gradually accumulated. This result was similar to those exhibited in date palm inoculated with $F$. oxysporum (Ramos et al., 1997). The responses of resistance in $H$. sabdariffa var. sabdariffa could be due to systemic induced resistance (SIR) described in carnation (Peer et al., 1991; Postma and Rattink, 1992), cucumber (Mandeel and Baker, 1991) and cassava (Dogbo et al., 2008). In $H$. sabdariffa var. altissima which is susceptible to $F$. oxysporum, the SIR was not efficient in spite of the high content of the phenolic compounds. The presence of these total phenols in altissima variety was probably constitutive and not essential in defense mechanisms. These compounds could be flavanes such as those observed in Solanum khasianum (Mühlenbeck et al., 1996). The role of phenols has been cited in a number of defense mechanisms against fungus in certain plants (Kuwabara and Katoh, 1999; Gümez-Vasquez et al., 2004).

The contents of the total phenols in the treated plants of sabdariffa variety (resistant variety) decreased significantly in nursery while it strongly increased in the treated plants of altissima variety (susceptible variety). This response could be explained by the high production and activity of polyphenoloxidase (PPO) which oxidises certain phenols into highly toxic quinones which were considered to play an important role in disease resistance (Concellün et al., 2004; Colak et al., 2005; Schweiggert et al., 2005; Dogbo et al., 2008; Damodaran et al., 2009).

There were no significant differences between resistant variety and susceptible variety for total chlorophyll and carotenes in culture in vitro and nursery. The attacks of plants by $F$. oxysporum had no significant effect on photosynthesis in $H$. sabdariffa. This result was similar to those obtained in strawberry (Zhao et al., 2009). Nevertheless, the negative action of $F$. oxysporum on roselle photosynthesis grown in rainy forest of Nigeria (Amusa et al., 2005) would be induced by the coordinated effect of another pathogenic agent. Such coordinated effect between $F$. oxysporum and biotic or abiotic agent induced the negative effects on photosynthesis in strawberry (Zhao et al., 2009).

Vegetative vigor of in vitro plantlets which were grown in tubes containing the MS medium was fairly 
correlated to vigor of plants in nursery. Thus, vigor observations in culture in vitro can explain a part of variation of this trait in nursery and can be used for the early screening of the adult vigor. For Darvishzadeh (2007), the fair correlations could be used to screen some genotypes at early stage.

Resistance of different inoculated plants represented by the high values of length, width and weight of leaves was negatively and significantly correlated to the content of total phenol. This result was another proof of early screening of resistance of $H$. sabdariffa plants against $F$. oxysporum. It is different from the result observed in Musa (Damodaran et al., 2009). Nevertheless, this method of rapid screening of resistant genotypes could be used in improvement program of $H$. sabdariffa such as that used in cocoa tree (Tahi et al., 2006).

\section{REFERENCES}

Agbenin ON and Ogunlana MO (2006) Occurence of Fusarium wilt and nematodes on red calyx roselle (Hibiscus sabdariffa L.) in northern Nigeria. J. Plant Prot. Res. 46 (2), 117-122

Akindahunsi AA and Olaleye MT (2003) Toxicological investigation of aqueous-methanolic extract of the calyces of Hibiscus sabdariffa L. J. Ethnophar. 89, 161-164

Akpan GA (2000) Cytogenetic characteristics and the breeding system of six Hibiscus species Theor. Appl. Gen. 100 (2): 315-318

Amusa NA, Adegbite AA and Oladapo MO (2005) Vascular Wilt of Roselle (Hibiscus sabdariffa L. var. sabdariffa) in the humid forest Region of South-western Nigeria. J. Plant. Path. 4 (2): 122-125

Boulanger J, Follin JC and Bourely J (1984) Les hibiscus textiles en Afrique tropicale, $1^{\text {ère }}$ partie: conditions particulières de production du kenaf et de la roselle. Cot. Fib. Trop $5^{\text {th }} \mathrm{Ed}$

Chen CC, Hsu JD, Wang SF, Yang MY, Kao ES, Ho YC and Wang CJ (2003) Hibiscus sabdariffa extract inhibits the development of astherosclerosis in cholesterol-fed rabbits. J. Agric. Food Chem. 51(18): 5472-5477

Cissé $M$, Dornier $M$, Sakho $M$, N'Diaye $A$, Reynes $M$ and Sock O (2009) Le bissap (Hibiscus sabdariffa L.): composition et principales utilisations. Fruits 64 (3): 179-193

Colak A, Özen A, Dincer B, Güner S and Ayaz A (2005) Diphenolases from two cultivars of cherry laurel (Lauroceracus officinalis Roem.) fruit at an early stage of maturation. Food Chem. 90: 801-807
Concellün A, Aòün $M C$ and Chaves AR (2004) Characterization and and changes in polyphenol oxidase from eggplant fruit (Solanum melongena L.) during storage at low temperature. Food Chem. 88: $17-24$

Damodaran T, Kumar N and Kavino M (2009) Breeding and evaluation of Musa hybrids resistant to Fusarium oxysporum f. sp. Cubense race 1. Fruits 64: 3-12

Darvishzadeh R, Dechamp-Guillaume G, Hewezi T and Sarrafi A (2007) Genotype-isolate interaction for resistance to black stem in sunflower (Helianthus annuus). Plant Path. 56 (4): 654-660

Dogbo DO, Békro JAM, Békro YA, Gogbeu SJ, Traoré A and Sié RS (2007) Influence de l'acide salycilique sur l'activité des polyphénoloxydases et l'accumulation des composés phénoliques chez le manioc (Manihot esculenta Crantz). Afr. Sci. 3 (2): 243-258

Dogbo DO, Békro JAM, Békro YA, Sié RS, Gogbeu SJ and Traoré A (2008) Influence de l'acide salycilique sur la synthèse de la phénylalanine ammonia-lyase, des polyphénoloxydases et l'accumulation des composés phénoliques chez le manioc (Manihot esculenta Crantz). Sci. Nat. 5 (1): 1-13

El-Hadrami I, Ramos $\mathrm{T}$ and Macheix J (1996) Caractérisation de nouveaux dérivés hydroxycinnamiques aminés chez Phoenix dactylifera L.: relation avec le brunissement des tissus et la résistance des cultivars au bayoud. Polyph. Comm. 2: $341-342$

El-Modafar C, Tantaoui A and El Boustani E (1999) Cinétique d'accumulation et fongitoxicité des phytoalexines du palmier dattier vis-à-vis de Fusarium oxysporum f.sp. albedinis. J. Phytopath. 147: 477-484

Faraji MH and Tarkhani AH (1999) The effect of sour tea (Hibiscus sabdariffa) on essential hypertension; J. Ethnopharm. 65: 231-236

Fathima M and Balasubramanian A (2006) Effect of plant growth regulators on the yield and quality of bast fibres in Hibiscus sabdariffa L. var. altissima Wester Intern. J. Bot. 2 (1): 48-55

Gawel NJ and Robacker CD (1990) Genetic control of somatic embryogenesis in cotton petiole callus cultures. Euphytica 49: 249-253

Gomez-Leyva JF, Acosta LAM, Muraira IGL, Espino HS, Ramirez-Cervantes F and Andrade-Gonzalez I (2008) Multiple shoot regeneration of roselle (Hibiscus sabdariffa L.) from a shoot apex system. Intern. J. Bot. 4 (3): 326-330

Hong V and Wrostlad O (1990) Use of HPLC separation/photodiode array detection for characterization of anthocyanin. J. Agric. Food Chem. 38: $708-715$ 
Kamei $\mathrm{H}$, Kojima $\mathrm{T}$, Hasegawa $\mathrm{M}$, Koide $\mathrm{T}$, Umeda $\mathrm{T}$, Yukawa T and Terabe K (1995) Suppression of tumor cell growth by anthocyanins in vitro. Cancer Invest. 13: $590-594$

Kuwabara $T$ and Katoh $Y$ (1999) Involvment of the binuclear copper site in the proteolytic activity of polyphenol oxidase. Plant Cell Physiol. 40: 1029-1035

Mandeel $Q$ and Baker R (1991) Mechanisms involved in biological control of Fusarium wilts of cucumber with strains of nonpathogenic Fusarium oxysporum. Phytopath. 81: 462-469

Michaelek S, Treutter D, Mayr U, Lux-Endrich A, Gutmann $M$ and Feucht W (1996) Role of flavan-3-ols in resistance of apple trees to Venturia inaequalis. Polyph. Comm. 2: 347-348

Mizukami H, Tomita K and Ohashi H (1989) Anthocyanin accumulation and changes in activities of phenylalanine ammonia-lyase and chalcone synthase in roselle (Hibiscus sabdariffa L.) callus cultures. Plant Cell Rep. 8 (8): 467-470

Mizukami H, Tomita K, Ohashi H and Hiraoka N (1988) Anthocyanin production in callus cultures of roselle (Hibiscus sabdariffa L.). Plant Cell Rep. 7 (7): 553-556

Morton J (1987) Roselle Hibiscus sabdariffa L. In: Morton JF (ed) Fruits of warm climates (pp 281-286) Miami FL.

Murashige $T$ and Skoog $F$ (1962) A revised medium for rapid growth and bioassays with tobacco tissue cultures. Physiol. Plant 15: 473-479

Mühlenbeck U, Kortenbusch A and Barz W (1996) Formation of hydroxycinnamoylamides and hydroxyacetovanillone in cell cultures of Solanum kharsianum. Phytochem. 42: 1573-1579

Oboh G and Elusiyam CA (2004) Nutrient composition and antimicrobial activity of sorrel drinks (soborodo). J. Med. Food 7 (3): 340-342.

Ooi KH and Saleh B (1999) Vegetative compatibility groups of Fusarium oxysporum, the causal organism of vascular wilt on roselle in Malaysia. Biotropia 12: 31-41

Peer R van, Niemann GJ and Schippers B (1991) Induced resistance and phytoalexin accumulation in biological control of Fusarium wilt of carnation by Pseudomonas sp. Strain WCS417r. Phytopath. 81: 728-734

Postma J and Rattink H (1992) Biological control of Fusarium wilt of carnation with a nonpathogenic isolate of Fusarium oxysporum. Can. J. Bot. 70 : 1199-1205

Ramos T, El Bellaj M, El Idrissi-Tourane A, Daayf $F$ and EI Hadrami I (1997) Les phénolamides des rachis de palmes, composants de la réaction de défense du palmier dattier vis-à-vis de Fusarium oxysporum f.sp. albedinis, agent causal du Bayoud. J. Phytopath. 145: 487-493

Schweiggert U, Schieber A and Carle R (2005) Inactivation of peroxidase, polyphenol oxidase and lipoxygenase in paprika and chili powder after immediate thermal treatment of the plant material Innov. Food Sci. Emerg. Technol. 6: 403-411

Sedra MH and Besri M (1994) Evaluation de la résistance du palmier dattier au bayoud causé par Fusarium oxysporum f.sp. albedinis. Recherches d'une méthode de discrimination des vitroplants acclimatés en serre. Agronomie 14: 467-472

Sié RS (2010) Caractérisation agro-morphophysiologique et micropropagation de l'oseille de Guinée (Hibiscus sabdariffa L.). PhD Thesis Université de Bretagne Occidentale, Brest (France) 165 pp

Spies JR (1955) Colorimetric procedure for amino acid and phenol in: Colowick S.P., Kaplan W.O. (Eds), Methods in enzymology, Acad. Press, New York, USA

Tahi GM, Kébé I, Eskes AB, Ouattara S, Sangaré A and Mondeil F (2000) Rapid screening of cacao genotypes for field resistance to Phythophthora palmivora using leaves, twigs and roots. Eur. J. Plant Pathol. 106: 8794

Tahi GM, Kébé I, Sangaré A, Mondeil F, Cilas C and Eskes AB (2006) Foliar resistance of cacao (Theobroma cacao) to Phythophthora palmivora as an indicator of pod resistance in the field : interaction of cacao genotype, leaf age and duration of incubation. Plant Pathol. 55: 776-782

Tsai P, Mcintosh J, Pearce P, Camden B and Jordan B (2002) Anthocyanin and antioxidant capacity in roselle (Hibiscus sabdariffa L.) extract. Food Res. Inter. 35 (4): 351-356.

Zhang B, Feng R, Liu F and Wang Q (2001) High frequency somatic embryogenesis and plant regeneration of an elite Chinese cotton variety. Bot. Bull. Acad. Sin. 42: 9-16

Zhao X, Zhen W, Qi Y, Liu X and Yin B (2009) Coordinated effects of root autotoxic substances and Fusarium oxysporum Schl. F. sp. fragariae on the growth and replant disease of strawberry. Front. Agric. China 3 (1): 34-39

Ziouti A, El Modafar C, Fleuriet A, El Boustani E and Macheix JJ (1992) Les polyphénols, marqueurs potentiels de la résistance du palmier dattier (Phoenix dactylifera L.) au Fusarium oxysporum h.sp. albedinis. C. R. Gr. Polyphénols 16: 346-349

Zouine $\mathrm{J}$ and El-Hadrami I (2004) Somatic embryogenesis in Phoenix dactylifera L. Effect of exogenous supply of sucrose on proteins, sugar, phenolics and peroxydases activities during the embryogenic cell suspension culture. Biotechnol. 3: 114-118 